\title{
Incidence of Snake bites in Dhanusha District of Nepal: a study in tertiary care centre
}

\author{
Mandal RN*, Ahmed Z*, Mishra A*, Das RC* \\ Department of Medicine \\ Janaki Medical College, Ramdaiya, Janakpur
}

* Department of Medicine, JMC

\begin{abstract}
Background and Objectives: Envenomation by poisonous snakes is considered as an occupational hazard. Snake bite is a common medical emergency and one of the important causes of mortality and morbidity in tropical region.

Material and Methods: The present study was conducted in the emergency department of JMCTH. All the patients admitted to JMCTH from April 2014 to November 2014 with snake bite were followed up from the time of admission to throughout their stay in hospital. The data was obtained from hospital case records, direct interrogation from relatives, friends, person accompanying the patients. The information was collected in a pre-formed Proforma. Data were entered and analyzed using Microsoft Excel.
\end{abstract}

Results: The victims of snake bite predominantly were male. Maximum numbers of snake bite cases were between the age group of 31 to 40 yrs and of low socio-economic status. $67.34 \%$ cases were from rural areas and farmers were the most common victim (69.38\%).

Conclusion: Maximum cases occurred during the summer and pre-monsoon months, during daytime and involved the lower limbs. Ptosis was the chief neurotoxic feature followed by dysarthria

Key words: Snake Bite, Incidence, dysarthria, emergency.

\section{INRODUCTION}

Snake bite is an injury caused by a bite from a snake often resulting in a punctured wound inflicted by the animal fangs and sometimes resulting in envenomation [1]. The majority of snake species are non - venomous and they typically killed their prey by constriction rather than venom. Venomous snake can be found on every continent except Antarctica [2].

Recent estimates indicate that somewhere between 1.2 million and 5.5 million snakebite occurs worldwide each year, with 421,000 1,841,000 envenomation and 20,000 - 94,000 deaths [3]. Such wide-ranging estimates reflect the challenges of collecting accurate data in the regions most affected by venomous snakes; many victims do not seek 
hospital treatment, and reporting and record keeping are generally poor[4]. There are more than 3500 species of snakes but only 250 are venomous [5].

In Nepal about 200 species are found of which 52 are poisonous and 1500 to 3000 people die every year out of about 30 thousand snake bite cases. Only 5 of them are dangerously poisonous to human e.g. King Cobra, common Cobra, Common Krait, Russell's Viper and Saw Scaled Viper [6]. The most common poisonous snake is Common Krait. The King Cobra lives in the dense rain forest of the hills and is common in surrounding area of Janakpur like Dhalkewar, Bardibas and adjoining areas.

A large number of deaths can be prevented with prompt treatment, timely administration of anti-venom and other supportive measures. The outcome of snake bites depends on numerous factors including the species of snake, the area of body bitten, the amount of venom injected and health condition of victim [7].

So the present study was carried to determine the various aspects of snake bite incidence such as age, sex, socio-economic status etc, and clinical manifestation of snake bite at Dhanusha, Janakpurdham, Nepal.

\section{MATERIALS AND METHODS}

This study was conducted in Department of Medicine JMCTH, Janakpur Nepal. All snake bite cases admitted at JMCTH, Janakpur from April 2014 to November 2014 were included in this study. During this period 49 snake bite cases were admitted. The data was obtained from hospital case records, direct interrogation from relatives, friends, person accompanying the deceased and deceased itself. All the patients admitted to JMCTH with snake bite were followed up from the time of admission to throughout their stay in hospital. The information was collected in a preformed Proforma which includes age, sex, occupation, seasonal distribution and clinical manifestation of snake bite etc, for each case. Data were analyzed using Excel.

Ethical clearance was obtained from the Institutional Ethics Committee prior to the commencement of the study.

\section{RESULTS}

Total number of male patients admitted in hospital due to snake bite were 30 (61.22\%) and female 19 (38.77\%) shown in Table 1. Table 2 shows, 18 victims were of age group 31 to 40 yrs (36.73\%) and least number of cases were under the age group of 10 (2.04 $\%)$. Farmers were the most common victims 34 (69.38\%) followed by labours $16.32 \%$, house - wife $6.12 \%$ and unknown $8.16 \%$ respectively (table 3 ).

Table 1: Sex Wise Distribution of Snake Bite Cases:

\begin{tabular}{|l|l|l|l|}
\hline S. N. & Sex & $\begin{array}{l}\text { No. of Snake } \\
\text { Bite Cases }\end{array}$ & Percentage \\
\hline 1. & Male & 30 & $61.22 \%$ \\
\hline 2. & Female & 19 & $38.78 \%$ \\
\hline \multicolumn{2}{|l|}{ Total } & 49 & $\mathbf{1 0 0} \%$ \\
\hline
\end{tabular}

Table 2: Age Wise Distribution of Snake Bite Cases:

\begin{tabular}{|c|c|c|c|}
\hline S N & Age Groups & $\begin{array}{c}\text { No. of Snake } \\
\text { Bite Cases }\end{array}$ & Percentage \\
\hline 1. & $0-10$ yrs. & 1 & $2.04 \%$ \\
\hline 2. & $11-20$ yrs. & 4 & $8.16 \%$ \\
\hline 3. & $21-30$ yrs. & 10 & $20.40 \%$ \\
\hline 4. & $31-40$ yrs. & 18 & $36.73 \%$ \\
\hline 5. & $41-50$ yrs. & 9 & $18.37 \%$ \\
\hline 6. & 51 - 60 yrs. & 5 & $10.20 \%$ \\
\hline 7. & $>60$ yrs. & 2 & $4.08 \%$ \\
\hline \multicolumn{2}{|r|}{ Total } & 49 & $100 \%$ \\
\hline
\end{tabular}

In the present study 33 victims (67.34\%) belong to rural population and rest $16(32.65$ $\%$ ) are from urban region (Table 4). Most 
snake bite cases were reported in the season of monsoons (June to September) 36 (73.46 $\%$ ) followed by summer (February to May) 11 $(22.44 \%)$ and winter (October to January) 2 $(4.08 \%)$ and maximum incidence of snake bites were during day time 30 (61.22 \%) which is shown in table 5 and 6 . Lower limbs were involved in maximum number of cases $32(65.30 \%)$ followed by upper limbs 14 (28.57\%) and trunk $3(6.12 \%)$ respectively (table 7). Table 8 shows the clinical manifestation of the snake bite. No clinical features were seen in $12.24 \%$ of cases.

Table 3: Victims Occupation

\begin{tabular}{|c|l|c|c|}
\hline SN & Occupation & $\begin{array}{c}\text { No. of Snake } \\
\text { Bite Cases }\end{array}$ & Percentage \\
\hline 1. & Farmer & 34 & $66.38 \%$ \\
\hline 2. & Labour & 08 & $16.32 \%$ \\
\hline 3. & House - wife & 03 & $06.12 \%$ \\
\hline 4 & Unknown & 04 & $08.16 \%$ \\
\hline \multicolumn{2}{|c|}{ Total } & $\mathbf{4 9}$ & $\mathbf{1 0 0} \%$ \\
\hline
\end{tabular}

Table 4: Showing Area Wise Distribution

\begin{tabular}{|c|l|c|c|}
\hline SN & \multicolumn{1}{|c|}{ Area } & $\begin{array}{c}\text { No. of Snake } \\
\text { Bite Cases }\end{array}$ & Percentage \\
\hline 1. & Rural & 33 & $67.34 \%$ \\
\hline 2. & Urban & 16 & $32.65 \%$ \\
\hline \multicolumn{2}{|c|}{ Total } & $\mathbf{4 9}$ & $\mathbf{1 0 0} \%$ \\
\hline
\end{tabular}

Table 5: Seasonal Distribution of Snake Bite Cases

\begin{tabular}{|c|l|c|c|}
\hline SN & Season & $\begin{array}{c}\text { No. of Snake } \\
\text { Bite Cases }\end{array}$ & Percentage \\
\hline 1. & Summer & 11 & $22.44 \%$ \\
\hline 2. & Monsoon & 36 & $73.46 \%$ \\
\hline 3. & Winter & 02 & $04.08 \%$ \\
\hline \multicolumn{2}{|c|}{ Total } & $\mathbf{4 9}$ & $\mathbf{1 0 0 \%}$ \\
\hline
\end{tabular}

Table 6: Diurnal Variation of Snake Bite Cases

\begin{tabular}{|c|l|c|c|}
\hline SN & $\begin{array}{c}\text { Diurnal } \\
\text { Variation }\end{array}$ & $\begin{array}{c}\text { No. of Snake } \\
\text { Bite Cases }\end{array}$ & Percentage \\
\hline 1. & Day time & 30 & $61.22 \%$ \\
\hline 2. & Night & 19 & $38.77 \%$ \\
\hline \multicolumn{2}{|c|}{ Total } & $\mathbf{4 9}$ & $\mathbf{1 0 0 \%}$ \\
\hline
\end{tabular}

Table 7: Shows Site of Snake Bite

\begin{tabular}{|c|l|c|c|}
\hline SN & Area of Bite & $\begin{array}{c}\text { No. of Snake } \\
\text { Bite Cases }\end{array}$ & Percentage \\
\hline 1. & Lower Limb & 32 & $65.30 \%$ \\
\hline 2. & Upper Limb & 14 & $28.57 \%$ \\
\hline 3. & Other Site & 3 & $06.12 \%$ \\
\hline \multicolumn{2}{|c|}{ Total } & $\mathbf{4 9}$ & $\mathbf{1 0 0 \%}$ \\
\hline
\end{tabular}

Table 8: Shows Clinical Manifestation of Snake Bite Cases

\begin{tabular}{|c|l|c|c|}
\hline SN & \multicolumn{1}{|c|}{ Clinical Features } & $\begin{array}{c}\text { No. of } \\
\text { Snake bite } \\
\text { Cases }\end{array}$ & $\begin{array}{c}\text { Percenta } \\
\text { ge }\end{array}$ \\
\hline 1. & $\begin{array}{l}\text { Local signs = Swelling, } \\
\text { punctured wound etc. }\end{array}$ & 9 & $18.36 \%$ \\
\hline 2. & $\begin{array}{l}\text { Systemic signs } \\
\text { Neurotoxic, Ptosis, } \\
\text { Dysarthria etc. }\end{array}$ & 7 & $14.28 \%$ \\
\hline 3. & Combined & 27 & $55.10 \%$ \\
\hline 4. & None & $\mathbf{4 9}$ & $12.24 \%$ \\
\hline \multicolumn{2}{|c|}{ Total: } & $\mathbf{1 0 0 \%}$ \\
\hline
\end{tabular}

\section{DISCUSSION}

In present study it was found that males were more affected than female. The other studies shows similar pattern. Hansdak et al. in their study showed that snake bite were $2.5 \%$ more in males than in females and body area maximum exposed for snake bite was the lower limbs and maximum incidence occurred during monsoon [6] which is consistent with the present study.

In this present study 18 victims were of age group 31 to 40 yrs (36.73\%) which is consistent with other studies. According to study done by Albuquerque et al. male were affected more than female [8]. Maximum victims were of age between 30 to $39 \mathrm{yrs}$, lower limb were the maximum affected area. Victims belonged maximum to rural areas and snake bite cases were seen mainly during rains. Age group of 30 to 50 yrs with a peak incidence of the victims in their third decade has been observed in the earlier studies in India and South East Asian Region [3]. In the present series farmers were the most common victims 34 (69.38\%) followed by labours $16.32 \%$, house - wife $6.12 \%$ respectively. According to the study of Nucci et al., males were more affected and the common age group of their study was $3^{\text {rd }}$ decade and the most bitten site was lower limbs, maximum victims were agricultural 
workers and maximum belong to rural areas [9]. The findings of their study are consistent with the findings of the present study.

\section{CONCLUSION:}

The present study shows that males were more affected than females. Maximum number of victims was aged between 31 to 40 yrs. Maximum snake bite occurred in outdoor especially in monsoon season, lower limb was more affected. Snake bite is a common medical emergency and one of the important causes of mortality and morbidity in tropical region. Each year tens of thousands of people die from snake bites. Yet the risk of being bitten can be lowered with preventive measures such as wearing foot wear and avoiding areas known to be inhabited by dangerous snakes.

\section{ACKNOWLEDGEMENT}

We express our cordial thanks to Principal of JMC, Janakpur; Emergency Medical Officer and staffs of Emergency Department for their co - operation, support, and constructive suggestions.

\section{REFERENCES}

1. Davidson's Principles \& Practice of Medicine, $21^{\text {st }}$ ed. 223 - 228pp.

2. Stephen S. The Dangerous Snakes of Africa: Natural History - Species Directory - Venoms and Snake bite, Sanibel Island, FL: Ralph Curtis Publishing, Bill Branch 1995.

3. Alirol E, Sharma SK, Bawaskar HS, Kuch U, Chappuis F. Snake bite in South Asia: A Review Negl Trop Dis 2010; 4: 603.

4. Sullivan JB, Wingert WA, Norris JRL. North American Venomous Reptile Bites, Wilderness Medicine: Management of Wilderness and Environmental Emergencies 1995; 3: 680 - 709.

5. Thope SR: Wuster W, Malhotra A. Venomous Snakes: Ecology, Evolution, and Snake bite, Oxford, England: Oxford University Press: 1996.
6. Hansdak SG, Laller KS, Pokharel P, Shyangwa P, Karki P et al. A clinico - epidemiological study of snake bite in Nepal. Trop Doct 1998; 28: 223 - 226.

7. Reddy KS. The essentials of Forensic Medicine and Toxicology 24th ed, 2005. 474pp.

8. Albuquerque HN, Fernandes A, Albuquerque ICS. Snake bite in Parabia, Brazil. J Venom Anim Toxins incl Trop Dis 2005; 11(3): 242 -251.

9. Nucci UKC. Shah RK., Reddy KS. Narayan. A study of snake bite poisoning in Gulbara region (a five year study). Indian J of Forensic Med \& Toxicol 2009; $3(2)$. 